Care: Jurnal Ilmiah Ilmu Kesehatan Vol .8, No.1, 2020, hal 127-137

Tersedia online di https://jurnal.unitri.ac.id/index.php/care

ISSN 2527-8487 (online)

ISSN 2089-4503 (cetak)

\title{
HUBUNGAN FREKUENSI PENYELAMAN, LAMA MENYELAM, PILEK, DAN MEROKOK, TERHADAP KEJADIAN BAROTRAUMA TELINGA TENGAH PENYELAM TRADISIONAL
}

\author{
Ishak Martinus $^{1)}$, Suharyo Hadisaputro ${ }^{2)}$, Munasik ${ }^{3)}$ \\ ${ }^{1), 2)}$ Magister Epidemiologi Sekolah Pascasarjana Universitas Diponegoro Semarang \\ ${ }^{3)}$ Fakultas Perikanan dan Ilmu Kelautan Universitas Diponegoro Semarang \\ E-mail: ishakmartinus@yahoo.co.id
}

\begin{abstract}
Inability to equate middle ear space pressure with the surrounding environment can cause tissue damage or barotrauma. Factors influencing the incidence of middle ear barotrauma in traditional divers are colds, smoking, frequency of diving and length of diving. The purpose of explaining the factors related to the occurrence of barotrauma in the middle ear of traditional breath-resistant divers. The analytic observational research design with cross sectional approach is supported by in-depth interviews, by conducting interviews using questionnaires and otoscopy examinations of respondents to determine the events of middle ear barotrauma. The study population was traditional divers, totaling 78 respondents. The dependent variable is the occurrence of barotrauma in the middle ear of traditional divers, the independent variable with colds, smoking habits, frequency of diving and length of diving, data analysis using bivariate and multivariate. Results as many as 32 people (41.0\%) of 78 respondents experienced middle ear barotrauma. Bivariate analysis showed a correlation between the frequency of diving with the events of the middle ear barotranama $p=0.012$. Logistic regression test showed the significance value of the frequency of diving $\geq 4$ days / week $(p=0.0106 ; P R=5.310 ; 95 \%$ $C I=1.619-17.413)$. Conclusion of factors related to the incidence of middle ear barotrauma in traditional divers is the frequency of diving hari 4 days / week, with a probability of $38.13 \%$.
\end{abstract}

Keywords: Barotraumas; frequency of dives; traditional divers.

\section{ABSTRAK}

Ketidakampuan menyamakan tekanan ruang telinga tengah dengan lingkungan sekitar dapat menimbulkan kerusakan jaringan atau barotrauma. Faktor yang mempengaruhi kejadian barotrauma telinga tengah pada penyelam tradisional yaitu pilek, merokok, frekuensi penyelaman dan lama menyelam. Tujuan menjelaskan faktor yang berhubngan kejadian

Cara mengutip: Martinus, Ishak., Hadisaputro, Suharyo \& Munasik. (2020). Hubungan Frekuensi Penyelaman, Lama Menyelam, Pilek, dan Merokok Terhadap Kejadian Barotraumas Telinga Tengah Penyelam Tradisional. Care:Jurnal Ilmiah Ilmu Kesehatan, 8(1), $127-$

Retrieved from https://jurnal.unitri.ac.id/index.php/care/article/view/1175 
barotrauma telinga tengah penyelam tradisional tahan nafas. Desain penelitian observasional analitik dengan pendekatan cross sectional di tunjang indepth interview, dengan melakukan wawancara mengunakan kuiseioner dan pemeriksaan otoskopi terhadap responden untuk mengetahui kejadian barotrauma telinga tengah. Populasi studi adalah penyelam tradisional, berjumlah 78 reponden. Variabel dependen kejadian barotrauma telinga tengah penyelam tradisional, variabel independen sakit pilek, kebiasaan merokok, frekuensi penyelaman dan lama menyelam, analisis data menggunakan bivariat dan multivariat. Hasil sebanyak 32 orang $(41,0 \%)$ dari 78 responden mengalami barotrauma telinga tengah. Analisis bivariat ada hubungan frekuensi penyelaman dengan kejadian barotrauama telinga tengah nilai $p=0,012$. Uji regresi logistik menunjukkan nilai signifikansi frekuensi penyelaman $\geq 4$ hari/minggu ( $p$ $=0,0106 ; \mathrm{PR}=5,310 ; 95 \% \mathrm{CI}=1,619-17,413)$. Kesimpulan faktor yang berhubungan kejadian barotrauma telinga tengah pada penyelam tradisional adalah frekuensi penyelaman $\geq 4$ hari/minggu, dengan probabilitas $38,13 \%$.

Kata Kunci : Barotrauma; frekuensi penyelaman; penyelam tradisional.

\section{PENDAHULUAN}

Penyelaman merupakan kegiatan yang dilakukan di dalam air atau penyelaman basah, dan penyelaman kering atau di dalam ruang udara bertekanan tinggi ( $R$ Riyadi S, 2016). Penyelaman merupakan suatu kegiatan mencari nafkah pada lingkungan kerja penyelaman (Ruslan RDC, 2005) yang memiliki banyak faktor risiko yang mempengaruhi kondisi fisik penyelam bahkan mempunyai risiko tinggi terhadap kejadian kesakitan, kelumpuhan/ kecacatan, sampai dengan kematian (Kemenkes RI, 2012). Risiko yang dimaksud tidak hanya akibat penyelaman, tetapi juga dipengaruhi oleh lingkungan bawah air, teknik penyelaman dan peralatan yang digunakan serta kondisi fisik dan mental penyelam, juga karena perbedaan tekanan (Jelita Bofe, 2014). Penyelam tradisional adalah orang yang melakukan kegiatan penyelaman dengan teknik tahan nafas dan dengan menggunakan suplai udara dari permukaan laut yang dialirkan melalui kompresor udara (Surface Supplied Breathing Apparatus (Kemenkes RI, 2013).

Permasalahan kesehatan penyelam tradisional umumnya dengan permasalahan lingkungan hiperbarik yaitu lingkungan bertekanan tinggi lebih dari 1 atmosfir. Perubahan tekanan pada kedalaman 17 kaki di bawah air setara dengan perubahan tekanan pada ketinggian 18.000 kaki diatas bumi. Dengan demikian, perubahan tekanan lingkungan terjadi lebih cepat pada saat menyelam. Perubahan tekanan relatif terbesar dalam menyelam terjadi pada kedalaman 10 meter pertama (PKHI, 2000). Dengan demikian cedera paling banyak terjadi pada kedalaman dangkal yaitu 4,3-17,4 kaki (1,3-5,3 meter), pada kedalaman tersebut dapat menyebabkan 
pecahnya membran timpani (Benz BG, et al. 2012). Perubahan tekanan udara dalam rongga udara fisiologis tubuh dengan tekanan disekitarnya, dapat menyebabkan kerusakan jaringan tubuh yang di sebut barotrauma, dapat terjadi pada bagian tubuh yang berongga, antara lain paru-paru, sinus-sinus paranasalis, dan telinga (R Riyadi S, 2016).

Barotrauma paling sering terjadi pada telinga tengah, hal ini terutama karena rumitnya fungsi tuba eustachius (Adams GL, et al. 1997). Barotrauma telinga tengah adalah masalah kesehatan yang umum pada penyelam, namun demikian, dapat dicegah jika penyelam mau menaati peraturan yang berlaku (Fyntanaki O, et al. 2013). Penyelam tradisional umumnya kurang memperhatikan hal-hal yang berhubungan dengan keselamatan dan kesehatan kerja, sehingga berpotensi terkena barotrauma telinga tengah (Kemenkes RI, 2003). Menurut Lynch JH, Bove AA. (2009) barotrauma telinga tengah terjadi pada $30 \%$ penyelam pemula dan $10 \%$ pada penyelam berpengalaman. Penelitian Goplen et al. (2009) di Statens dykekerskole (Norwegian State Diving School) menemukan 17 dari 47 penyelam atau 36\% penyelam mengalami barotrauma telinga tengah. Depkes RI (2008) menyatakan bahwa di Kepulauan Seribu, Pulau Panggang dan
Pulau Pramuka Indonesia, tahun 1994-1996 sebanyak 41,37\% penyelam mengalami barotrauma telinga. Prasetyo dkk. (2011) menyatakan angka kejadian barotrauma pada penyelam tradisional di Banyuwangi sebanyak 32,4\% dari 74 orang penyelam, dan yang menderita barotruma telinga tengah sebanyak $83,3 \%$.

Berdasarkan hasil penelitian Jellyta (2014), menyatakan dari 60 responden penyelam tradisional, terdapat penyelam tahan napas $33,3 \%$, dan pernah menderita gejala awal penyakit penyelaman yaitu pusing/sakit kepala $(21,2 \%)$, perdarahan hidung dan telinga (7,5\%). Di Balaesang Tanjung penyelaman dilakukan hampir setiap hari tanpa menggunakan peralatan selam, pada kedalaman $<10$ meter, dalam melakukan penyelaman sebagian besar peselam melakukan kegiatan di dasar laut 1 - 2 jam. Semakin lama penyelam di bawah permukaan air artinya semakin lama terpapar dengan tekanan dan semakin sering untuk menyamakan tekanan (ekualisasi), maka semakin besar pula kemungkinan gagal dalam menyamakan tekanan. Frekuensi atau seringnya penyelam melakukan aktivitas penyelaman dalam satu minggu lebih dari 4 hari, sehingga kemungkinan risiko terjadinya keluhan akibat penyelaman semakin besar. Penyelam tahan nafas akan lebih banyak 
frekuensi menyelam karena penyelaman tersebut tidak mampu bertahan lama di kedalaman, sehingga harus naik turun ke permukaan untuk mendapatkan suplai udara (Tuti Ekawati, 2005).

Menurut G Adam, et al. (1997) dan Carl Edmonds, et al. (2012) menyatakan bahwa semakin sering seorang penyelam menyelam akan lebih sering terjadi trauma tekanan berulang pada telinga tengah dan dalam, menyebabkan penciutan tuba eustachius dan organ keseimbangan pada telinga dalam, mengalami pembengkakan jaringan dan penyumbatan pada tuba eusthacius, yang dapat menyebabkan kegagalan ekualisasi.

Semua Penyelam di lokasi penelitian belum pernah mendapatkan penyuluhan tentang kesehatan penyelaman, sehingga penyelam kurang mengetahui tentang bagaimana cara menyelam yang sehat, dan lebih dari $55 \%$ penyelam menyatakan merokok dan juga mengkonsumsi alkohol sebelum melakukan penyelaman. Pendapatan penyelam per bulan masih banyak yang di bawah Rp. 500.000,- hanya cukup untuk kebutuhan sehari-hari, sehingga untuk mendapatkan penghasilan yang lebih penyelam kadang mengabaikan kondisi kesehatannya dalam melakukan kegiatan penyelaman. Sakit pilek dan kebiasaan merokok dalam kesehatan penyelaman pada dasarnya dapat menghambat proses ekualisasi dimana sakit pilek menimbulkan reaksi inflamasi yang mengakibatkan hipersekresi dan penumpukan lendir membuat ekualisasi menjadi sulit, atau bahkan tidak mungkin dilakukan.

Ekualisasi adalah ketidakampuan menyamakan tekanan ruang telinga tengah dengan lingkungan sekitarnya sehingga menyebabkan kerusakan jaringan atau barotrauma. Barotrauma telinga dapat terjadi apabila penyelam tidak melakukan ekualisasi tekanan telinga tengah secara benar (Benz BG, et al. 2012).

Mengingat besarnya masalah yang ada pada penyelam tradisional di Balaesang Tanjung, maka perlu dilakukan penelitian barotrauma telinga tengah pada penyelam tradisional. Tujuan penelitian adalah menjelaskan faktor yang mempengaruhi kejadian barotrauma telinga tengah penyelam tradisional tahan nafas.

\section{METODE PENELITIAN}

Desain peneletian observasional analitik, dengan studi cross-sectional ditunjang dengan penelitian kualitatif, melalui indepth interview. Populasi penelitian adalah semua penyelam tradisional tahan nafas di Kecamatan Balaesang Tanjung Kabupaten 
Donggala Propinsi Sulawesi Tengah, yang berjumlah 78 penyelam. Teknik pengambilan sampel menggunakan total sampling, sampel penelitian adalah semua penyelam tradisional tahan nafas yang memenuhi kriteria inklusi dan eklusi. Adapun kriteria inklusi yaitu penyelam masih aktif, lebih diutamakan pada penyelam pemula, penyelam dengan usia minimal 16 tahun, dan bersedia menjadi responden sedangkan kriteria eklusinya penyelam yang mempunyai riwayat sakit telinga. Kejadian barotrauma telinga tengah didiagnosa dengan pemeriksaan otoskopi terutama untuk melihat gendang telinga (Soepardie EA, 2000). Variabel dependen pada penelitian ini adalah kejadian barotrauma telinga tengah pada penyelam tradisional tahan nafas di Balaesang Tanjung, sedangkan variabel independen sakit pilek, kebiasaan merokok, frekuensi penyelaman, dan lama menyelam.

Pengumpulan data primer dari wawancara mendalam terhadap responden, dan pemeriksaan fisik telinga oleh dokter puskesmas di damping dokter dari RSUD Undata Palu. Data sekunder diperoleh dari hasil pencatatan atau pelaporan Puskesmas Malei, dan Kantor Kecamatan Balaesang Tanjung, dan dilanjutkan indepth interview pada responden yang didiagnosis barotrauma telinga tengah. Alat yang digunakan pada penelitian ini yaitu otoskop, stopwatch untuk mengukur waktu, HP untuk merekam wawancara dan dokumentasi, tali pengukur, dan kuisioner.

Data yang diperoleh dianalisis secara statistik dengan analisis univariat, bivariat dengan menggunakan uji Chi-Square dan analisis multivariat regresi logistik ganda dengan metode enter. Tingkat signifikansi ditetapkan pada 0,05. Penelitian ini telah ditinjau dan disetujui oleh Komite Etik Penelitian Kesehatan (KEPK) Fakultas Kedokteran, Universitas Diponegoro dan Rumah Sakit dr. Kariadi Semarang. Ethical clearance nomor 618/EC/FK-RSDK/XI/ 2018.

\section{HASIL}

Tabel 1. Distribusi Kejadian Barotrauma Telinga Tengah pada Penyelam Tradisonal

\begin{tabular}{lcccccc}
\hline \multirow{2}{*}{$\begin{array}{c}\text { Kejadian barotrauma } \\
\text { telinga tengah }\end{array}$} & $\mathrm{f}$ & & & \multicolumn{4}{c}{ Telinga } \\
\cline { 4 - 7 } & & & & \multicolumn{2}{c}{ Kanan } & \multicolumn{3}{c}{ Kiri } \\
\cline { 4 - 7 } & & & $\mathrm{f}$ & $(\%)$ & $\mathrm{f}$ & $(\%)$ \\
\hline Ya & 32 & 41.0 & 20 & 25,6 & 19 & 24,4 \\
Tidak & 46 & 59.0 & 58 & 79,9 & 59 & 75,6 \\
\hline Jumlah & 78 & 100.0 & 78 & 100.0 & 78 & 100.0 \\
\hline
\end{tabular}


Pemeriksaan fisik telinga penyelam (25,6\%) mengalami barotrauma telinga tradisional dengan menggunakan otoskopi, tengah pada telinga kanan, dan sebanyak diperoleh hasil sebanyak 32 responden $19(24,4 \%)$ penyelam tradisional $(41,0 \%)$ mengalami barotrauma telinga mengalami barotrauma telinga tengah pada tengah. Sebanyak 20 penyelam tradisional telinga kiri (Tabel 1).

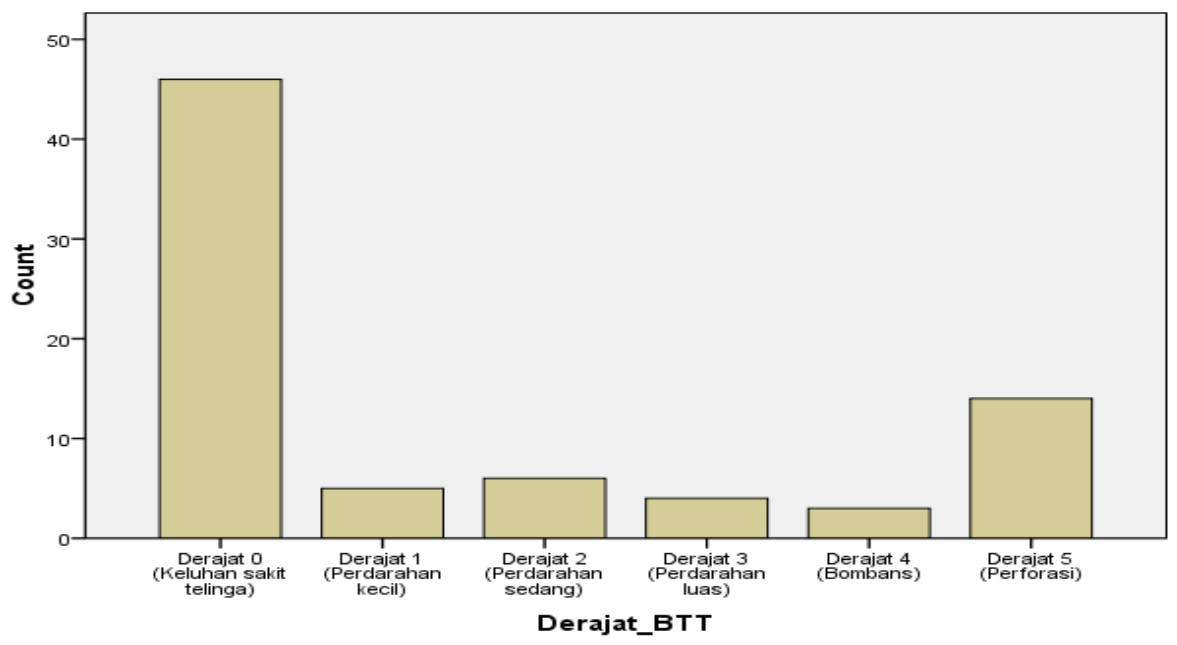

Gambar 1. Derajat Barotrauma Telinga Tengah pada Penyelam Tradisonal

Gambar 1 menunjukkan berdasarkan kelainan gendang telinga pada penyelam tradisional dengan kategori derajat 0 atau hanya keluhan sakit telinga ada 46 orang $(59,0 \%)$, derajat I atau perdarahan kecil pada gendang telinga ada 5 orang $(6,4 \%)$, derajat II atau perdarahan sedang pada gendang telinga ada 6 penyelam $(7,7 \%)$, derajat III atau perdarahan luas pada gendang telinga ada 4 penyelam $(5,1 \%)$, derajat IV atau gendang telinga bombans tampak biru gelap karena adanya perdarahan ada 3 penyelam $(3,8 \%)$, dan derajat $\mathrm{V}$ atau terjadi perforasi gendang telinga ada 14 penyelam (17,9\%).
Berdasarkan Tabel 2 didapatkan bahwa lama menyelam, sakit pilek, kebiasaan merokok dengan nilai $p>0,05$, sehingga hipotesis penelitian tidak terbukti, dan disimpulkan tidak ada pengaruh dari ketiga faktor tersebut dengan kejadian barotrauma telinga tengah, sedangkan untuk frekuensi penyelaman diperoleh nilai $p$-value $=0,012(p<0,05)$ dengan tingkat kemaknaan $\propto=0,05$. Maka dapat disimpulkan bahwa hipotesis penelitian terbukti, artinya secara statistik ada hubungan frekuensi penyelaman dengan kejadian barotrauma telinga tengah pada penyelam tradisional, dan lama menyelam dengan nilai $p$-value $=0,107(p<0,25)$ 
merupakan variabel kandidat untuk (Tabel 3).

dilanjutkan dalam analisis multivariat

Tabel 2. Hasil Analisis Bivariat

\begin{tabular}{|c|c|c|c|c|c|c|c|}
\hline \multirow{2}{*}{$\begin{array}{c}\text { Variabel } \\
\text { Independen }\end{array}$} & \multicolumn{4}{|c|}{ Barotrauma Telinga Tengah } & \multirow[t]{2}{*}{ P value } & \multirow[t]{2}{*}{ PR } & \multirow[t]{2}{*}{$95 \% \mathrm{CI}$} \\
\hline & \multicolumn{2}{|c|}{$\mathrm{Ya}$} & \multicolumn{2}{|c|}{ Tidak } & & & \\
\hline & & & & & & & \\
\hline$\geq 7$ Menit & 12 & 30,8 & 27 & 69,2 & 0,107 & 0,422 & $0.167-1,065$ \\
\hline$<7$ Menit & 20 & 51,3 & 19 & 48,7 & & & \\
\hline \multicolumn{8}{|l|}{ Frekuensi Penyelaman } \\
\hline$\geq 4$ hari/minggu & 27 & 51,9 & 25 & 48,1 & $0,012^{*}$ & 4,536 & $1.485-13,857$ \\
\hline$<4$ hari $/$ minggu & 5 & 19,2 & 21 & 80,8 & & & \\
\hline \multicolumn{8}{|l|}{ Sakit Influenza } \\
\hline Ya & 13 & 50,0 & 13 & 50,0 & 0,371 & 1,737 & $0.669-4,508$ \\
\hline Tidak & 19 & 36,5 & 33 & 63,5 & & & \\
\hline \multicolumn{8}{|l|}{ Kebiasaan Merokok } \\
\hline Ya & 20 & 36,4 & 35 & 63,6 & 0,297 & 0,524 & $0.196-1,403$ \\
\hline Tidak & 12 & 52,2 & 11 & 47,8 & & & \\
\hline
\end{tabular}

Keterangan : ${ }^{*}$ nilai $p<0,05$ hasil signifikan

Tabel 3. Hasil Analisis Bivariat dengan $p$ value $<0,25$

\begin{tabular}{llcc}
\hline \multicolumn{1}{c}{ Variabel } & $\boldsymbol{p}$ value & $\boldsymbol{P R}$ & $\mathbf{9 5 \%} \mathbf{C I}$ \\
\hline Lama Menyelam $\geq 7$ Menit & 0,107 & 0,442 & $0,167-1,065$ \\
$\begin{array}{l}\text { Frekuensi Penyelaman } \geq 4 \\
\text { hari/minggu }\end{array}$ & 0,012 & 3,920 & $1,405-10,936$ \\
\hline
\end{tabular}

Hasil analisis multivariat dengan uji regresi logistik ganda dengan metode enter pada tingkat kemaknaan 95\% menunjukkan frekuensi penyelaman $\geq 4$ hari/minggu secara statistik, berpengaruh dan merupakan faktor risiko kejadian barotrauma telinga tengah pada penyelam tradisional di Balaesang Tanjung dengan $p$ $=0,006 ; \quad \mathrm{PR}=0,442, \quad 95 \%$ CI $=$ 1,619-17,413 (Tabel 4).

Tabel 4. Hasil Analisis Multivariat Bermakna secara Statistik

\begin{tabular}{lrcrc}
\hline \multicolumn{1}{c}{ Variabel } & $\mathrm{B}$ & p value & PR & $95 \%$ CI \\
\hline Frekuensi Penyelaman $\geq 4$ hari/minggu & 1.366 & 0,006 & 5,310 & $1,619-17,413$ \\
Constant & -2.154 & & & \\
\hline
\end{tabular}

\section{PEMBAHASAN}

Penyelam tradisional yang mengalami barotrauma telinga tengah sebanyak 32 orang $(41,0 \%)$ dan 20 orang $(25,6 \%)$ mengalami pada telinga kanan, 19 orang (24,4\%) mengalami pada telinga kiri dengan kelainan gendang telinga terbanyak pada derajat $\mathrm{V}$ atau terjadi perforasi 
gendang telinga sebanyak 14 orang $(17,9 \%)$.

Faktor risiko sakit pilek atau kebiasaan merokok dalam kesehatan penyelaman pada dasarnya dapat menghambat proses ekualisasi dimana sakit pilek menimbulkan reaksi inflamasi yang mengakibatkan hipersekresi dan penumpukan lendir membuat ekualisasi menjadi sulit, atau bahkan tidak mungkin dilakukan hal ini dikarenakan sakit pilek merupakan salah satu faktor predisposisi terhadap disfungsi tuba eustachius (Soepardie EA, 2000), sedangkan kebiasaan merokok dapat menyebabkan iritasi selaput lendir pada saluran pernafasan. Paparan asap rokok menyebabkan inflamasi mukosa pada telinga tengah dan tuba eustachius. Fungsi tuba eustachius yang terganggu akan menyebabkan gangguan ventilasi telinga tengah (kegagalan ekualisasi). Penyebab gangguan fungsi tuba eustachius bermacam-macam, salah satunya adalah kebiasaan merokok (Hussain TA,2010). Pada penelitian ini faktor risiko kebiasaan merokok tidak terbukti sebagai faktor yang berpengaruh terhadap kejadian barotrauma telinga tengah. Harianingrum A, dkk (2017) dalam penelitiannya menunjukkan insidensi gangguan fungsi tuba eustachius pada perokok sebesar $74,7 \%$.
Hasil indepth interview dengan informan penyelam, mengatakan bahwa:

....Kami menyelam untuk memenuhi kebutuhan hidup keluarga, walau dalam kondisi sakit kami tetap menyelam, apalagi kalo cuma sakit pilek atau batuk...

....Minum alkohol dan merokok untuk menghilangkan rasa dingin saat menyelam dan sambil menunggu jaring terisi ikan, kami mengkonsumsi cap tikus dan merokok...

Lama menyelam tidak terbukti menjadi faktor risiko yang berpengaruh terhadap kejadian barotrauma telinga tengah, saat dilakukan analisi multivariat menunjukkan hasil yang tidak bermakna secara statistik $p=0,133(p>0.05)$. Berbeda dengan hasil penelitian yang dilakukan oleh Navisah SF, dkk. (2016), yang membuktikan bahwa lama menyelam memiliki hubungan yang signifikan terhadap kejadian barotrauma telinga tengah. Semakin lama penyelam di bawah permukaan air artinya semakin lama terpapar dengan tekanan dan semakin sering untuk menyamakan tekanan (ekualisasi), maka semakin besar pula kemungkinan gagal dalam menyamakan tekanan tersebut. Jika gagal melakukan ekualisasi akan berisiko mengalami barotrauma telinga (PKHI, 2000). Variabel lama menyelam pada penenlitian ini tidak terbukti secara statistik sebagai faktor yang 
Care: Jurnal Ilmiah Ilmu Kesehatan Vol .8, No.1, 2020, hal 127-137

berpengaruh terhadap kejadian barotrauma telinga tengah penyelam tradisional, kemungkinan dikarenakan paparan tekanan lingkungan pada penyelam tidak lama karena penyelam tahan nafas biasanya waktu menyelamnya tidak lama, hanya beberapa menit saja (Depkes, 2008).

Frekuensi penyelaman $\geq 4$ hari/minggu terbukti menjadi faktor risiko barotrauma telinga tengah penyelam tradisional, setelah di analisis multivariat hasil bermakna secara statistik dengan nilai $p<$ 0,006, PR=5,310 (95\% CI=1,619-17,413), memberikan arti bahwa frekuensi penyelaman $\geq 4$ hari/minggu memiliki risiko terjadi barotrauma telinga tengah sebesar 5,310 kali lebih besar dibanding dengan penyelam tradisional yang melakukan aktivitas penyelaman $<4$ hari/minggu.

Penelitian ini sejalan dengan penelitian Cecil C Ramos. et al. (2005) yang menunjukkan bahwa frekuensi penyelaman sering atau berulang - ulang ada hubungan yang signifikan terhadap kejadian barotrauma jaringan membrane timpani. Begitu juga penelitian oleh Tuti Ekawati (2005) menyatakan ada hubungan yang bermakna antara faktor risiko atau seringnya penyelaman dengan kejadian barotrauma membrane timpani pada penyelam tradisional dengan nilai $p=$ 0,011 ( $p<0,05)$ dan Sugianto (2014) menyatakan bahwa frekuensi penyelaman ada hubungan dengan kejadian barotrauma telinga membrane timpani.

Penyelam tahan nafas akan lebih banyak frekuensi menyelam karena penyelaman tersebut tidak mampu bertahan lama di kedalaman, sehingga harus naik turun ke permukaan untuk mendapatkan suplai udara (Tuti Ekawati, 2005). Menurut G Adam, et al. (1997) dan Carl Edmonds, et al. (2012) menyatakan bahwa semakin sering seorang penyelam menyelam akan lebih sering terjadi trauma tekanan berulang pada telinga tengah dan dalam, tuba eustachius akan tertekan, menyebabkan penciutan tuba eustachius dan organ keseimbangan pada telinga dalam, mengalami pembengkakan jaringan dan penyumbatan pada tuba eusthacius. Jika tuba eusthacius tersumbat maka tekanan di dalam telinga tengah berbeda dengan tekanan di luar gendang telinga, menyebabkan terjadi perforasi gendang telinga bahkan telinga mungkin akan terlihat berdarah (Depkes RI, 2002).

Hasil indepth interview dengan informan penyelam, mengatakan bahwa: ....Kami menyelam hampir setiap hari, untuk memenuhi kebutuhan hidup 
keluarga...

....Kami menyelam dalam satu hari bisa 2 sampai 4 kali, untuk melihat jaring tersangkut di karang atau sudah ada ikan yang masuk dalam jaring tidak tergantung dari jenis hasil tangkapan...

\section{KESIMPULAN}

Faktor yang berpengaruh terhadap kejadian Barotrauma telinga tengah adalah frekuensi penyelaman $\geq 4$ hari/minggu, dengan probabilitas terhadap kejadian Barotrauma telinga tengah pada penyelam tradisional sebesar 38,13\%.

\section{SARAN}

Perlu peningkatan pengetahuan penyelam tradisional melalui penyuluhan atau penyebarluasan informasi tentang faktor risiko barotrauma telinga tengah dan pelatihan teknik penyelaman yang benar dan aman, bekerjasama dengan instansi atau organisasi dibidang penyelaman.

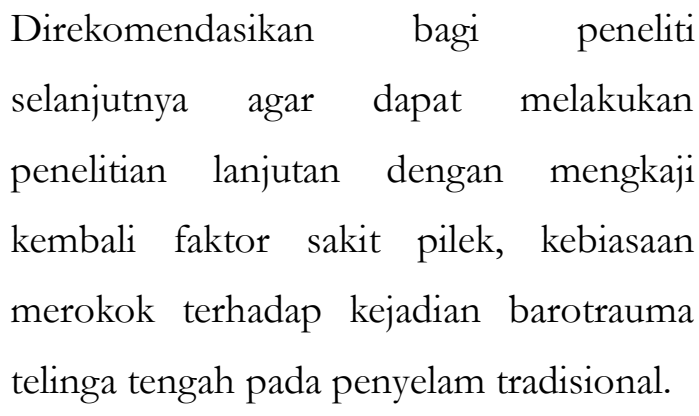

\section{REFERENSI}

Adams G, Boies L, Higler P. Boies. (1997).
Buku Ajar Penyakit THT. Jakarta: EGC

Bentz BG, Hughes CA. (2012) Barotrauma :American Hearing Research Foundation. Northwestern University. USA

http://american-hearing.org/disorder s/barotrauma/

Bofe J. (2014). Implementasi Kebijakan Kesehatan Peselam Di Kecamatan Balaesang Tanjung Kabupaten Donggala, Tesis, Pasca Sarjana Program Studi Magister Administrasi Publik: Universitas Tadulako Palu

Depkes RI. (2008). Petunjuk Tehnis Upaya Kesehatan Penyelaman Dan Hiperbarik Bagi Petugas Kesehatan Propinsi, Kabupaten/Kota Dan Puskesmas. Jakarta: Direktorat Jendral Pengendalian Penyakit dan Penyehatan Lingkungan.

Depkes RI. (2012). Pedoman Upaya Kesehatan Kerja Bagi Nelayan Penyelam Tradisional: Panduan bagi Petugas Kesehatan. Jakarta: Pusat Kesehatan Kerja

Edmonds C, Mc Kenzei B, Thomas R, Pennefather J. (2013). Diving Medicine for SCUBA Divers 5 th Edition 2013. Published by Carl Edmonds Ocean Royale, 11/69-74 North Steyne Manly, NSW, 2095 Australia ISBN : 978-0-646-57276-0.2012.

Ekawati T. (2005). Analisis Faktor Risiko Barotrauma Membran Timpani pada Penyelam Tradisional di Kecamatan Semarang Utara Kota Semarang. Tesis, Pasca Sarjana Program Studi Magister Kesehatan Lingkungan: Universitas Diponegoro

Goplen FK, dkk. (2010). Vestibular Effects of Diving -a 6-year Prospective Study. Occupational Medicine.

Harianingrum A, Naftali Z, Marliyawati D. (2018). Pengarub Derajat Merokok. Terbadap Fungsi Tuba Eustachius Pada Perokok Aktif. Jurnal Kedokteran Diponegoro

Hussain TA. (2010). Effect of active smoking on the tympanometry findings in adult men. J Fac Med 
Baghdad

Kemenkes RI. (2012). Penyakit Akibat Kerja karena Pajanan Hiperbarik dan Penyakit lain Akibat Penyelaman. Jakarta: Direktorat Jenderal Bina Kesehatan Kerja dan Olah Raga

Kemenkes RI. (2013). Profil Kesehatan Nelayan. Jakarta: Direktorat Kesehatan Kerja

Lynch JH, Bove AA. (2009). Diving Medicine : A review of current evidence : Clinical Review. JABFM

Navisah SF, dkk. (2016). Faktor Resiko

Barotrauma Telinga pada Nelayan Penyelam di Dusun Watu Ulo Desa Sumberejo Kecamatan Ambulu Kabupaten Jember. Jurnal IKESMA.

Perhimpunan Kesehatan Hiperbarik Indonesia (PKHI). (2000). Pengantar Ilmu Kesehatan Penyelaman. Jakarta

Prasetyo AT, Soemantri JB, Lukmantya. (2012). Pengarub Kedalaman dan Lama Menyelam Terbadap Ambang-Dengar Penyelam Tradisional dengan Barotrauma Telinga. ORLI

R Riyadi S. (2016). Ilmu Kesehatan Penyelaman dan Hiperbarik. 2 ed. Surabaya: Lakesla

Ramos CC, dkk. (2005). Clinical and Tympanometric Findings in Repeated Recreational Scuba Diving.Travel Medicine and Infectious Disease

Ruslan RDC, dkk. (2015). Analisis Gangguan Pendengaran pada Penyelam di Danau Tondano Desa Watumea Kecamatan Eris Kabupaten Minahasa Provinsi Sulawesi Utara 2014. Jurnal e-Biomedik (eBM)

Soepardie EA, dkk. (2000). Buku Ajar Imu Kesehatan Telinga Hidung Tenggorok Kepala Leher, edisi ke empat, Jakarta: Fakultas Kedokteran Universitas Indonesia

Sugianto. (2014). Beberapa Faktor yang Berpengarub Terbadap Barotrauma Membran Timpani pada Penyelam Tradisional di Kabupaten Banyuwangi. Tesis, Pasca Sarjana Program Studi Magister Epidemiologi: Universitas Diponegoro. 